\title{
Bureaucracy Ethics Based in Public Service Local Wisdom in Gowa
}

\section{Muhammad Idris}

Doctoral Candidate in Public Administration, Universitas Negeri Makassar

\section{Muhammad Ramli}

Professor of Public Organization, Universitas Islam Negeri

\author{
Andi Agustang \\ Professor of Sociology Department, Universitas Negeri Makassar
}

\section{Andi Ima Kesuma}

Professor of Sociology Department, Universitas Negeri Makassar

Email: midriss256@gmail.com,mramli@gmail.com, andiagust63@gmail.com, a.imakesuma@gmail.com

Doi:10.5901/mjss.2015.v6n6s4p419

\begin{abstract}
Government bureaucracy, especially the implementation of local public services into the public spotlight due to the lack achieves effective results, transparency, and the lack of assurance services. The performance of the public service is still low, especially the attitude and behavior of the Ministry apparatus less attentive to the moral principles in the conduct of its work. Government officials as civil servants and the Royal Society still looked at the issue of the ethics of bureaucracy, i.e. morality as an element that is less important to the world of public service. The purpose of this study was to assess the public service, especially service of Building Permit (IMB) through the application of ethical values based on local wisdom, include; honesty, scholarship, adherence, and persistence. Assessing the problem with a phenomenological approach, namely, the researchers describe the experience done and experienced by the informants both IMB nomination processes, as well as the manufacture of IMB. The results showed that the attitude and behavior of a bureaucratic apparatus in the service of IMB remain low because there is still a bureaucratic practice of pathology seen from indicators of application of the values of honesty, scholarship, adherence and persistence.
\end{abstract}

Keywords: Bureaucratic Ethics, Local Wisdom, Public Service.

\section{Introduction}

The performance of public services in Indonesia, especially public service, is still very low. This is reinforced by the conclusions of the World Bank reported in the World Development Report 2004 and the results of research governance and Decentralization Survey (GDS) in 2002. Research GDS 2002, (Dwiyanto, 2003) found there are three important issues regarding the implementation of public service, namely; (1) the high discrimination in services, including: nepotism, political aspects, ethnic and religious. (2) There is no certainty of cost and service time, so it is not free from corruption and bribes. (3) The low level of public satisfaction with services as a result of discrimination and uncertainty services.

The reality of public services, particularly service's Building Permit (IMB) assessed the community is still far from true public service. Act No. 25 of 2009 on public service asserted that the public service is the right of every citizen that must be met and is a duty and responsibility of the government to organize it so that the basic rights of citizens guaranteed by the constitution. In line with the views and wishes of bureaucratic reform public services, that the government must realize the importance of good governance (good governance), especially public service delivery in the public interest in transparency comprehensive, efficient, and lack of certainty of service.

Licensing services is the responsibility of the Government officials as civil servants and the Royal Society to give satisfaction to the public. The reality is still a common abuse of authority and responsibility to push or force the desire to communities without considering the consequences morally. Officials and personnel licensing waiter more established itself as ruler rather than as a public servant. 
The bad behavior of bureaucratic licensing services can be seen from some of the views and findings of the scientists, as follows:

1. Dwiyanto (2008, p. 2) see that is still widespread practices of KKN (corruption, collusion, and nepotism) in the public service. KKN does not only make the service bureaucracy becomes very difficult enjoyed fairly by the people, but also people have to pay more expensive services.

2. Muhtar $(2010$, p. 22) found many irregularities or corrupt behavior in the public service. This practice as a result of cultural factors (culture) which include; the tradition of giving gifts to officials (officials) and family ties as well as more parochial loyalty.

3. The results of the survey KPPOD and The Asia Foundation (2011, p. 2-6) found that the licensing service is still not satisfactory for public as a result of the low performance of services, as follows:

a. Most of the area has not followed the standards set by the central government (maximum three days), the fact of the fastest six-day settlement permit.

b. The low level of participation on the ownership permit.

c. Most areas do not yet have an efficient service system, free extortion, collusion and free.

\section{Literature Review}

\subsection{Ethical Dimension Bureaucratic Public Service}

Thought on the importance of public service ethics in governance, in line with the formulation of Max Weber's ideal type bureaucracy that assesses and describes in his book (The theory of social and economic organization, 1922), known as the ideal type that is the ideal of academic bureaucracy is bureaucracy more focuses on aspects of rationality, impersonal and efficiency in improving the performance of government bureaucracy (Weber, 1964, p. 333). By because that, although the government bureaucracy continues to deal with the phenomenon in a rational power but should still from the attitudes and behavior of officials / officers who respect and uphold the law and moral values that apply.

However, in its development of government bureaucracy tends rated public is fewer sympathetic and bad connotation because it is less in favor of the society, but the bureaucracy serves as a public servant.

Kumorotomo, (2005, p. 13) It suggests some purpose formulation is Government Ethics; (1) formulate moral values I ethics, norms and responsibilities in the interrelation, interaction and interdependence between state officials and between state institutions at the central and local levels, (2) Reinforce the moral and material responsibility in his role as an organizer of the state administration and governance, especially in relation to the implementation of the tasks, functions and authorities in each as officials / agencies / government agencies and state agencies, (3) Set the governance relationship between the authority and responsibility of officials / institutions / agencies with based on moral values and the provisions of the applicable law, (4) provides a reference / guide as standard values in attitude and acts vertically or horizontally appropriate to authority and role of each officer / agency in conjunction with the institutional structure of governance according to applicable regulations. Therefore, ethical governance approach can deliver bureaucratic rationality and efficiency of public services with an indicator of transparency, accountability, participation and the rule of law.

Attitudes and behaviors that are considered well according to the ethical views are expressed Alder (1984) matching the views of The Liang Gie (1989) and Komorotomo (2008) can be seen from the six bases of the value of the indicator, namely: (1) truth, (2) goodness, (3) beauty, (4) freedom, (5) equality, and (6) justice. The cornerstone of this ethical asset value serve as guidelines for humans to undertake the consideration and action so that the attitudes and behaviors that can be considered good and ethically accountable.

Associated with the view of the ethical values that govern the behavior and attitude, especially in the public service bureaucracy, then Haryatmoko (2011: 6) describes a public service ethic contains three dimensions, quality of service, modalities (care facilities) and acts of service. The third dimension can be described by measuring good bureaucratic service with indicators; service objectives, accountability, transparency, neutrality, and public integrity.

\subsection{Dimensions Local Wisdom}

Local knowledge is one of the dimensions of moral values and a reference or local community attitude and behavior. When confronted by the concept of good governance, especially concerning the foundation of good behavior, the concept of local wisdom adopts the values principles, advice, norms and behavior ancestors in the past were considered important and had the ability to arrange things or to deal with various phenomena that occur in people's lives. For 
example, the service bureaucracy that is often considered less satisfactory because of the behavior of the apparatus, so that the arrangement or the effort to create good governance cannot be achieved with either.

Said (2007, p. 14) explains the local wisdom as a local wisdom or local knowledge or local intelligence "local genius, a view of life, science, and life strategy's intangible activities undertaken by the local community in responding to various problems in the fulfillment of their needs. Pangarsa (2007, p. 452) considers local wisdom as the embodiment of social capital in the communities in a joint problem-solving effort in the principle of equality and pair-together individuals who exist in a multi-compound. In this case, social capitals in the communities are values that become real ethics steering the daily behavior of each member of society.

Local wisdom is meant knowledge or values, principles, advice or thoughts that serve intelligence world view as the basis of ethics and moral assessment. As formulated by Mattulada (1985, p. 87) as the rationale Latoa and also written in Lontara that pattern of thinking the Bugis-Makassar in social life and culture, can be summed up into three sections, namely (1) people who always see themselves as being. The same social rank in the presence of God Almighty, (2) The man who always looked his goal to always do well, and (3) people who constantly build values and cultural and social institutions create harmony between the collective interests with the interests of the individual.

Assuming the three patterns of attitude that underlies the thinking of those first, to form the embodiment of the values and norms of social-cultural, called panngaderreng. In line with this, thinking is reinforced by the results of research Rahim (1985, p. 144), explaining that according to Toriolo, which determines man, is functioning and involvement of human nature, so that people become human (cultural values Bugis-Makassar).

The value of culture is referred to as the core values that should perform its role in the activities, both among individuals and societal institutions are; (1) the value of honesty, (2) the value of scholars, (3) the value of compliance, and (4) the value of persistence. Therefore, to create good governance, it is necessary to apply the values of local wisdom by modifying the substance of these values in the principles of good governance.

\subsection{Dimensions of Public Service}

Sinambela $(2010$, p. 5) gives the definition of public service as the fulfillment of the wishes and needs of the community by state officials. The state established by the public (public) course with the aim to improve the welfare of the community. In essence, in this case, the state government (bureaucrats) must be able to meet the needs of the community. Requirements for this case are not the individual needs, but the various needs of the real expected by society.

Public service is a service activity undertaken by the government as civil servants and the public to meet the needs of the people who organized the appropriate implementation of the provisions of the legislation. Regulation of the Minister for Administrative Reform, Numbers: 09/PER/M.PAN/5/2007, about the performance of the apparatus of State, referred to the performance of government agencies is an overview of the level of achievement of the goals or objectives of government agencies as the elaboration of the vision, mission and strategic plan of the government agency that indicates the success and failure of implementation of activities in accordance with program and policy set.

Sinambela, $(2010$, p. 6$)$ argues that the purpose of public service satisfy the community. Achieve satisfaction was demanded excellent service quality that is reflected; transparency, accountability, conditional, participatory, equal rights, and the balance of rights and obligations. In line with Dwiyanto (2006, p. 50-51), describes some of the indicators used to measure the performance of public bureaucracy, namely; productivity, quality of service, responsiveness, responsibility, and accountability.

\section{Methodology}

This study used a qualitative approach with an emphasis on phenomenology. The study focused at Integrided Public Service Office in Gowa Regency. Therefore, for the needs of data collection, researchers conducted primary data collection in the form of in-depth interviews on informant's official or service personnel. Researchers also conducted indepth interviews with service users. In addition, the researchers conducted a study of secondary data such as document data obtained by researchers in the form of archives list IMB maintenance and so on and Letters permit that has been issued the last two years in the scope of the Integrated Licensing Services Office. Both data sources tested its credibility and then interactively analyzed using a model of Miles and Huberman.

The focus and goal of research are the informants involved either directly or indirectly in the implementation of the licensing service in the last two years, ie since the year 2013 to 2014 in the scope of the Integrated Licensing Services Office, namely (1) The official decision-making related to the licensing policy in the Village and District, (2) implementing 
employee, (3) the registration section, (4) section field surveys, (4) the financial part, (5) parts of the issuance of licenses, (6) public or service users.

\section{Results and Discussion}

Thoughts on the importance of ethics in governance, especially bureaucratic quality public services and has previously described a variety of concepts and theories that support good governance of public service that promotes public interest in transparency, efficient, and lack of certainty of service. Although the empirical development of public service bureaucracies tends to be judged people fewer sympathetic and bad connotation because it is less in favor of the interests of the community. In theory, bureaucracy serves as a public servant. It examines the phenomenon of public services, particularly services building permit (IMB) in Gowa will be described below:

\subsection{Dimensional Destination}

One measure of the quality of service is a dimension that is the goal waiter initial orientation for deliberation and action. IMB service objective is the bureaucracy of public services must provide services in a professional manner to promote the interests of public service users of the personal interests or organizational.

IMB service execution in Gowa based on standards defined by the Office of Integrated Services as a joint commitment in providing excellent service by the vision, i.e. "In the Licensing Service Areas." The standard of service is a commitment / promise that should be implemented as the duties and responsibilities of public service personnel.

Results of the analysis of Theresa through interviews showed that IMB service has many issued permits to build but has not shown the commitment attitudes and behaviors corresponding apparatus for full-service responsibility in performing their duties. Commitment IMB service personnel in performing their duties with high responsibility can be seen in the matrix of the interview:

\begin{tabular}{|c|c|c|}
\hline No. & Standard Services & Data Results Interview \\
\hline 1 & Rates and Time & $\begin{array}{l}\text { a. Rates levied under the existing provisions, but often there are an additional fee-based } \\
\text { services provided and agreed. } \\
\text { b. Regarding the completion time often permits not timely because of the completeness } \\
\text { and readiness of technical implementation in the field of human resources. }\end{array}$ \\
\hline 2 & $\begin{array}{l}\text { The Infrastructure Ministry } \\
\text { \& Means }\end{array}$ & $\begin{array}{l}\text { The service infrastructure is already available to provide services but have not been able to } \\
\text { meet the demands of an increasingly complex society and more modern. }\end{array}$ \\
\hline 3 & Competence HR & $\begin{array}{l}\text { The number of employees who provide services reasonably available, despite having levels } \\
\text { varying capabilities in providing services, especially technicians in the field. }\end{array}$ \\
\hline 4 & $\begin{array}{l}\text { Information services and } \\
\text { complaint's handling }\end{array}$ & $\begin{array}{l}\text { a. The information services system has been prepared in such a way; it is just that people } \\
\text { have not utilized optimally, so it is still rated community lacking transparency. } \\
\text { b. Complaint handling service has not been implemented effectively because people have } \\
\text { not utilized and is limited to complaints. }\end{array}$ \\
\hline
\end{tabular}

Based on the quantitative results of these interviews has been a lot of the issued permit, but in the quality of service based on the purpose of public service is still far from the expectations of society. Public service users are often faced by the problem of uncertainty services when they are dealing with the bureaucracy, be it the requirements, tariffs, time, service management and information disclosure. Therefore, not a few people prefer the street to use brokers (intermediaries) to get a building permit.

\subsection{Dimensions Accountability}

One indicator of the institution's ability modalities provides public service is a must "Accountability" means that the size of a good service can indicate a bureaucratic activity performed in accordance with the norms and values shared by the community, and the service can meet the real needs of the community. IMB licensing service bureaucracy is an organization that has the legitimacy to carry out various policies and regulations regarding public service in the field of licensing. Therefore, as a government organization given the high moral responsibility to provide services to the public. This is certainly a great responsibility to be supported with the capability of personnel who provide services in an accountable and responsible.

Integrated Services Office of Gowa is one government organization that continues to provide public services in the field of licensing. A great expectation from the public as users of services is the realization of a quality service and meet 
accountability standards. It was found that the moral responsibility and professional responsibilities held official or officials assessed the community is still relatively low. An assessment of the accountability of service bureaucracy can be seen in the matrix of the interview, the following:

\begin{tabular}{|c|l|l|}
\hline No & Indicators Values and Attitude & Data Results Interview \\
\hline 1 & Concern and Responsibility & $\begin{array}{l}\text { Indeed, we get service, but less satisfactory because we are when we are not appreciated. } \\
\text { Our time is consumed by waiting for hours without any certainty of settlement permits. }\end{array}$ \\
\hline 2 & Commitment & $\begin{array}{l}\text { Employee behavior is not firm in providing services, in case there are rules that must be } \\
\text { used as a reference so that sometimes the treatment is different, both the cost and time of } \\
\text { completion. }\end{array}$ \\
\hline 3 & Initiatives and Awareness & $\begin{array}{l}\text { Services through the counter too long because back and forth from the village to the } \\
\text { District just to meet the administrative requirements according to the provisions without } \\
\text { considering the purpose of the service. }\end{array}$ \\
\hline
\end{tabular}

This fact shows that the dimensions of accountability IMB service is still relatively low. Service process becomes more rigid with only running services that are functional bureaucracy so that people cannot choose, but it should be subject to rules made by himself. Therefore, discovered many service users select a shortcut for not passing the existing procedures but through intermediaries (brokers). It is precise to give bureaucratic birth pathologies, such as corruption, collusion, and nepotism.

\title{
4.3 Dimensions of Transparency
}

One of the demands of stakeholders is that the transparency of service delivery practices overall. Service delivery process, in particular, the maintenance service of Building Permit (IMB) is required for the openness and ensures access for all users to the service to the various information processes established policy. For example, the government provides a form of action, the time, or how to take action should be provided access to information for the public and stakeholders openly.

Based on the results of research and observation on the implementation of services in the field of licensing (IMB) in Gowa, it has not been fully carried out openly, especially access to information related to the provisions that have been established as the standard of service. Disclosure of the information is conveyed through the board to talk about the mechanics of obtaining a license, but the timing and magnitude of costs are not communicated publicly so that it is still possible corrupt practices and abuse of official authority.

The results of interviews with the people who use the services of openness in providing services IMB says that;

\begin{abstract}
Actually quite open information services delivered to the public because there has been working mechanism on display around the waiting room but were not informed how long the permit will be completed and how much should be paid the levy in accordance with this regulation. Customer community just resigned just waiting for the decision of the apparatus without being given space to express their opinions or denial of services provided.
\end{abstract}

\subsection{Dimensions Neutrality}

One of the principles of public service is the principle of neutrality, namely the ability to condition the servicing activities and instead emphasize the functioning of public services. Neutrality is an action that puts public service in situations and conditions that are needed so it would not be possible simply to give priority to a single party or a group of specific groups. Neutrality means not favoring or services without discrimination but can meet the demands of liability and objectivity in providing information.

The results showed that IMB service in Gowa still tends to manifest the principles that are less neutral in providing services to all users of the service. This fact can be seen in the matrix of the following interview:

\begin{tabular}{|l|l|l|}
\hline No & Indicators Values And Attitude & Data Results Interview \\
\hline 1 & Justice Ministry & $\begin{array}{l}\text { We've got imb services but was treated unfairly by people who are known, let alone delivered by } \\
\text { intermediaries. Similarly, the completion of their license more quickly and not have to commute to the } \\
\text { village. }\end{array}$ \\
\hline 2 & Discrimination & $\begin{array}{l}\text { Sometimes we are lazy to take care of itself permit because, according to the experience of people who } \\
\text { had been working in imb said the better looking of the board or ask for help only the village or district. } \\
\text { Usually faster and undifferentiated although a little more costly. }\end{array}$ \\
\hline
\end{tabular}


This fact shows there is still a tendency lack of a neutrality officer in providing services, such as checking the file, the time, and a service attitude. This has implications for the low level of public participation to take care of themselves IMB. Besides, it also has implications for the behavior of the apparatus due to the low expectation of reward or thanks outside income as a civil servant.

\section{Conclusion}

Based on the results of analysis of this study, the authors concluded that the service of Building Permit (IMB) in Gowa still low seen from the aspect of ethics bureaucratic approach. IMB services through the Office of Integrated Services in quantity it can address the needs of the community regarding the settlement IMB but are still considered low quality because it has not fulfilled the public service quality indicators, such as (1) the dimensions of service objectives, (2) the dimensions of accountability services, (3) Transparency services, and (4) the neutrality of service.

Low fact IMB service ethic may occur based on the findings are; either official or bureaucratic apparatus and public service users have the attitude and behavior of an increasingly distant from the values of local wisdom as the moral basis for deliberation and action. Local wisdom values, namely the values of honesty, scholarship, adherence, and persistence is one of the local culture or cultural values "siri" na "pace" for the people of Gowa that should be applied in the attitudes and behavior of the bureaucracy of public service.

\section{References}

Ahmad, Badu. (2008). Bureaucracy condition of Indonesia in Relation to the Public Service. Journal of Public Administration, 4 (1), 4552.

Anonymous. (2011). Restoring Public Trust Through Reforms. Jakarta: PT. Gramedia Pustaka Utama.

Asrom, Hafidh. (2007). Pancasila, Local Wisdom and Regional Development. Journal of Philosophy, 17 (2), 201-213.

Bertens, K. (2011). Ethics. Jakarta: PT Gramedia Pustaka Utama.

Denhardt, Janet V., and Denhardt, Robert B. (2013). New Public Service. (Translated by Saut Pasaribu). Bantul: Creative Discourse.

Dwiyanto, Agus. (2008). Public Bureaucracy Reform in Indonesia. Yogyakarta: Gadjah Mada University Press.

Haryatmoko. (2011). For the Public Ethics for Public Officials and Political Integrity. Jakarta: PT Gramedia Pustaka Utama.

KPPOD and the Asia Foundation. (2012). Tata kelolah Regional Economy in 20 District / City PERFORMANCE Program Participant.

Jakarta: The Asia Foundation.

Kumorotomo, Wahyudi. (2008). Accountability of Public Bureaucracy Siesta In Transition. Yogyakarta: Student Library.

Muhtar, Entang Adhy. (2010). Public Services in Indonesia in Cultural Perspective. Journal of Public Administration, 1 (1), 17-24.

Munadah, Agussalim. (2005). Bureaucratic behavior People Makassar in Gowa An Analysis of Political Anthropology. (Unpublished Dissertation). Makassar: Hasanuddin University Graduate Program.

Pangarsa, Galina Widjil. (2006). Human resource development Insightful Local Wisdom Development Towards Sustainable Built Environment. Scientific Journal of Public Administration, 7 (1), 450-462.

Siagian, Sondra P. (1994). Bureaucracy pathology; Analysis, Identification and Treatment. Jakarta: Ghalia Indonesia.

Sinambela, Lijan Poltak. (2010). Public Service Reform, Theory, Policy, and Implementation. Jakarta: Earth Literacy.

The Liang Gie. (1989). Ethics Administration. Yogyakarta: Foundation for Science and Technology in Yogyakarta.

Weber, Max. (1964). Theory of Soscial and Economic Organization. USA: The Free Press.

Zeithaml, Valarie A., Parasuraman, A., and Berry, Leonard L. (1990). Delivering Quality Services-: Balancing Customer Perceptions and Expectations. New York: The Free Press. 